\title{
Implementation of hydroacoustic for a rapid assessment of fish spatial distribution at a Brazilian Lake - Lagoa Santa, MG
}

Aplicação do método hidroacústico na avaliação rápida da distribuição espacial de peixes em um Lago Brasileiro - Lagoa Santa, Minas Gerais

José Fernandes Bezerra-Neto ${ }^{1}$, Ludmila Silva Brighenti ${ }^{2}$ and Ricardo Motta Pinto-Coelho ${ }^{3}$

${ }^{1}$ Laboratório de Ecologia e Conservação, Departamento de Biologia Geral, Instituto de Ciências Biológicas, Universidade Federal de Minas Gerais - UFMG, CEP 31270-901, Belo Horizonte, MG, Brazil e-mail: joseneto@icb.ufmg.br

${ }^{2}$ Programa de Pós-graduação em Ecologia, Conservação e Manejo da Vida Silvestre, Universidade Federal de Minas Gerais - UFMG, CEP 31270-901, Belo Horizonte, MG, Brazil e-mail: ludmilasb@gmail.com

${ }^{3}$ Laboratório de Gestão Ambiental de Reservatórios Tropicais, Departamento de Biologia Geral, Instituto de Ciências Biológicas, Universidade Federal de Minas Gerais - UFMG, CP 486, CEP 31270-901, Belo Horizonte, MG, Brazil e-mail: rmpc@icb.ufmg.br

\begin{abstract}
Aim: To study the distribution, structure, size and density of fish in the karst lake: Lagoa Central (Lagoa Santa, MG - surface area: $1.7 \mathrm{~km}^{2}$; mean depth: $4.0 \mathrm{~m}$; and maximum depth: $7.3 \mathrm{~m}$ ). Methods: The hydroacoustic method with vertical beaming was applied, using the echosounder Biosonics DT-X with a split-beam transducer of $200 \mathrm{kHz}$. The analysis of the acoustic data was performed with the software Visual Analyzer (Biosonics Inc.). Thematic maps of density echoes associated with fish, estimated by the technique of echo-integration, were made using the kriging interpolation. The density and vertical distribution of insonified fish were estimated using the technique of echo-counting. Results: The lake had a mean density of 0.89 echoes associated with fish per $\mathrm{m}^{2}$, showing large spatial variations in the density of fish. The size estimated for the echoes associated with fish range from 2.7 to $15.9 \mathrm{~cm}$ (mean $=5.3 \mathrm{~cm}$ ). Conclusions: The use of hydroacoustic to obtain rapid and realistic estimates of fish abundance and vertical distribution of the fish stock was successful.
\end{abstract}

Keywords: ichthyofauna, density, fisheries, Lagoa Santa.

Resumo: Objetivos: Estudar a distribuição, densidade e estrutura de tamanho de peixes nas águas da Lagoa Central (Lagoa Santa, MG - área: 1,7 km²; profundidade média: 4,0 m; e profundidade máxima: 7,3 m). Métodos: $\mathrm{O}$ estudo utilizou o método hidroacústico com orientação vertical. Uma sonda Biosonics DT-X, equipada com um transdutor split-beam de $200 \mathrm{kHz}$, foi utilizada. A análise dos dados acústicos foi feita com o programa Visual Analyser (Biosonics Inc.). Mapas temáticos de densidades dos ecos associados a peixes, estimadas através da técnica de eco-integração, foram confeccionados utilizando a interpolação kriging. Já o número e distribuiçấo vertical dos peixes insonificados foram determinados utilizando a técnica de eco-contagem. Resultados: A Lagoa Central apresentou uma densidade média de 0,89 ecos associados a peixes por $\mathrm{m}^{2}$, indicando grandes variaçóes na densidade dos peixes em áreas particulares do lago. A estimativa de tamanho dos ecos associados a peixes variou de 2,7 a 15,9 cm (média $=5,3 \mathrm{~cm}$ ). Conclusóes: $\mathrm{O}$ uso de hidroacústica para obter estimativas rápidas e realistas de abundância de peixes e distribuiçáo vertical da população de peixes foi bem sucedida.

Palavras-chave: ictiofauna, densidade, recurso pesqueiro, Lagoa Santa.

\section{Introduction}

The measurement of fish density from traditional methods (e.g. nets and traps) demands a great effort, time and financial resources (Uieda and Castro, 1999). The use of nets, for example, is rather limited in determining the spatial distribution and the behavior patterns of fish populations. An alternative to these traditional procedures is the recent development of hydroacoustic equipments (Trevorrow, 1998; Mehner and Schulz, 2002; Ehrenberg and Steig, 2003; Chen et al., 2009). The 
fishing sonars enable the continuous visualization of the pelagic zone and allow the study of aquatic organisms that have biological structures filled with gas and, therefore, reflect the sound waves depending on the density difference between these structures and the environment. Those reflections are detected along the navigation throughout the water column (Simmonds and MacLennan, 2005).

The use of hydroacoustic technologies on fishing research showed a substantial development in the 1970s, when the echo-integration technique was introduced. This technique allowed estimates of schools density, unlike the echo-counting technique that had been employed (MacLennan and Holliday, 1996). Since then, the use of the method for assessment and management of fisheries, species identification and acoustic characterization, behavioral and trophic relationships studies have been widely described in literature (Gerlotto, 1993; Paramo et al., 2003; Vehanen et al., 2005). Among the advantages of acoustic methods, we can emphasize the fact that it is a non-invasive method allowing the exploration of large areas in a relatively short period of time with high, spatial and temporal, resolution (Godlewska and Jelonek, 2006). Echo sounding can provide basic information not only on fish stocks and spatial and temporal distribution, but also on zooplankton (eg Chaoborus), which is the main food resource of juvenile fishes and of some adult species (Godlewska and Jelonek, 2006). Another aspect to consider is that the hydroacoustic technique offers the possibility of obtaining simultaneous data on the lake sediments, bathymetry, and coverage of submerged macrophytes (Wheeler, 2005; Winfield et al., 2007a, b).

Recent technological developments, including significant reduction in size, plus the high degree of sophistication of hydroacoustic instrumentation (hardware and software) have led to an increase in the use of this technology in freshwater environments, particularly lakes (Wanzenböck et al., 2003). However, the use of hydroacoustics for the assessment of the fish fauna of the continental lentic ecosystems in Brazil has not followed the same trend viewed in other countries. Although many studies have demonstrated the application of those techniques in the marine environment (Travassos et al., 1999; Madureira and Rossi-Wongtschowski, 2005), adaptations to Brazilian inland waters are virtually absent (Krumme, 2004).

This study aimed to carry out a hydroacoustic survey on the Central Lake in order to get echo records potentially assignable to fish and to group them into echo-types or echo-standards considering the backscattered acoustic energy, the values of target strength and spatial and vertical distribution.

\section{Material and Methods}

\subsection{Study area}

The study was conducted in Central Lake, also known as Lagoa Santa, in the municipality of Lagoa Santa, Minas Gerais (19 $38^{\prime} \mathrm{S}$ and $43^{\circ} 53^{\prime} \mathrm{W}$ ), about $40 \mathrm{~km}$ north of Belo Horizonte (Figure 1). This is an exorheic lake, at $740 \mathrm{~m}$ altitude, with catchment area of $12.7 \mathrm{~km}^{2}$ a perimeter of 6467.20 $\mathrm{m}$, surface area of $1.7 \mathrm{~km}^{2}$, volume of $7 \times 10^{6} \mathrm{~m}^{3}$, and maximum and average depth of 7.3 and $4.0 \mathrm{~m}$, respectively (Brighenti et al., 2011).

Lagoa Santa lake system belongs to the "Lagoa Santa Karst". For many years, this region attracted the attention of researchers, mainly from paleontology and botany and, despite the high number of springs and lakes, limnological studies in these environments only began in the seventies (Carvalho et al., 1977).

As all water bodies surrounded by urban areas, the Central Lake has suffering large impacts of urbanization, resulting in increasing rates of eutrophication and sedimentation (Santos et al., 1998). Impacts on the diversity of fishes were detected by Pompeu and Alves (2003), who noted the disappearance of $70 \%$ of the 19 species recorded by Johannes Reinhardt, who made the first fish survey in 1850 . The most famous was the extinction of Characidium lagosantense, a small fish typical of the region, probably due

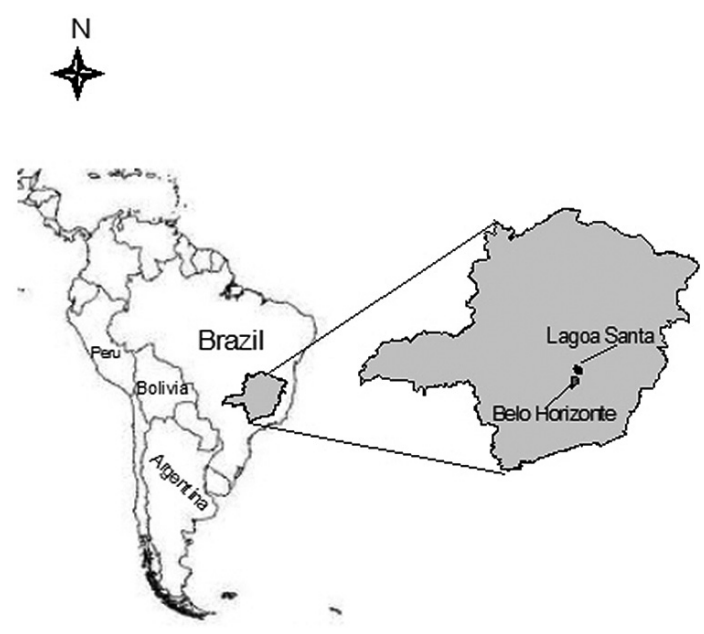

Figure 1. Localization of Lagoa Santa town, Minas Gerais state, Brazil. 
to: (a) obstruction of natural communication with rio das Velhas, formerly held by the stream Bebedouro (now channeled and heavily polluted), (b) introduction of exotic species, and (c) the elimination of marginal and submerged vegetation (Pompeu and Alves, 2003). Nine fish species are know for the lake, Astyanax lacustris, Eigenmannia micróstoma, Hoplias malabaricus, Rhamdia quelen, Pamphorichthys hollandi, Serrapinus heterodon, Cichla cf. monoculus, Hoplias lacerdae, Hoplosternum littorale and Tilapia rendalli, being the last four alien species.

\subsection{Acoustic survey}

The hydroacoustic study in Central Lake was held on April 28, 2008, during the day, using the echosounder Biosonics DT-X (Biosonics Inc.) equipped with a digital transducer split-beam, $200 \mathrm{kHz}, 6.6^{\circ}$. The digital echo sounder was coupled with a differential global positioning system (DGPS) AgGPS 132 (Trimble Co.). The GPS receiver had the coordinate data adjusted in situ from the satellite differential corrections (OmniSTAR, Inc.). Thus, the data collected by the positioning unit were adjusted in real time, allowing to obtain an error less than $100 \mathrm{~cm}$ at the position of the boat.

The transducer was set on a metal frame on the side of the vessel, positioned approximately $0.5 \mathrm{~m}$ below water surface, with the sonar beam vertically oriented. Before the beginning of acoustic recordings, the echosounder was calibrated using a standard target of known Target Strength (TS), a $36 \mathrm{~mm}$ tungsten carbide sphere provided by the equipment manufacturer. The calibration sphere was placed to about $5 \mathrm{~m}$ below the transducer positioned in the beam sonar, and approximately 2,000 pings were recorded to estimate the level of individual acoustic reflection (Target Strength - TS). The TS is the ratio between the energy that is reflected from a target and the amount of energy that focuses on this target (Simmonds and MacLennan, 2005). This test indicated that the system had an offset of 1.5. The Visual Analyzer software version 4.1 (Biosonics Inc.) was supplied with this compensation value for analyzes. In the prospecting, the echo sounder was adjusted to a pulse duration of $0.4 \mathrm{~ms}$ and a pulse rate of 5.0 pings per second (Table 1), the echo sounder default values.

To ensure efficient cover of the whole lake surface, an acoustic scan was conducted in ten transects parallel and perpendicular to the maximum length of the pond (Figure 2), the speed of the vessel was maintained at approximately $8 \mathrm{~km} \cdot \mathrm{h}^{-1}$.

Transects were previously defined using the software GPS TrackMaker ${ }^{\circledR}$; At first it was bounded on the line outside the Central Lake (Lagoa Santa, MG) using a high resolution satellite image obtained from Google Earth ${ }^{\circledR}$. This image was georeferenced from control points collected in the vicinity of the lake with a D-GPS (Differential Global Positioning System) GTR-A ${ }^{\circledR}$ (TechGeo Ltda.). The georeferencing and scanning of border line were carried out in Didger 3.0 ${ }^{\circledR}$ (Golden Software Inc.). The border line was imported to GPSTrackMaker ${ }^{\circledR}$ and transects were drawn with the aid of the tools of this program and imported to the Garmin ${ }^{\circledR}$ GPS via a serial cable.

The total distance covered during the entire study was $8.7 \mathrm{~km}$, representing a degree of coverage

Table 1. Parameters of initial settings of echo sounder (Biosonics DT-X - split-beam, $200 \mathrm{kHz}$ ) to collect field data.

\begin{tabular}{|c|c|}
\hline Parameter & \\
\hline Water temperature $\left({ }^{\circ} \mathrm{C}\right)$ & 28.0 \\
\hline Salinity (ppt) & 0.0 \\
\hline Assumed sound speed $\left(\mathrm{m} . \mathrm{s}^{-1}\right)$ & 1504.16 \\
\hline Transducer depth (m) & 0.5 \\
\hline Pulse duration (ms) & 0.4 \\
\hline Pulse rate (pps) & 5 \\
\hline Absorption coefficient $\left(\mathrm{dB} \cdot \mathrm{m}^{-1}\right)$ & 0.00693 \\
\hline Detection threshold $(\mathrm{dB})$ & -130 \\
\hline Transducer beam width ( $3 \mathrm{~dB}$ angle) & 6.6 \\
\hline Directivity index $(\mathrm{dB})$ & -29.26 \\
\hline
\end{tabular}

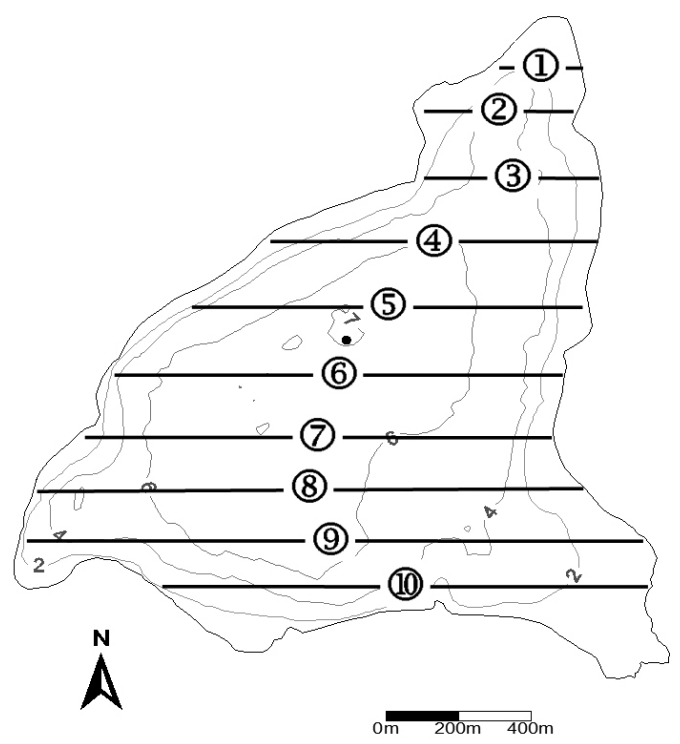

Figure 2. Bathymetric chart of central Lake (Lagoa Santa, MG, Brazil) showing the ten transects followed during the acoustic survey. 
(d) 6.6. The degree of coverage (d), as proposed by Simmonds and MacLennan (2005), relates the extension of acoustic scanning and the surface prospected, obtained by the Equation 1:

$\mathrm{d}=\frac{\mathrm{D}}{\sqrt{\mathrm{A}}}$

where, $\mathrm{D}=$ total length of the Cruise track; and $\mathrm{A}=$ size of the area being surveyed. According to these authors, to an appropriate level of coverage, the value of "d" should not be less than 4.0.

The information processed by the echo sounder were visualized in real time and stored in individual files for each transect in a notebook connected to the acoustic equipment (via ethernet). The Visual Acquisition software version 5.0 (Biosonics Inc.) was used for visualization, digital storage, configuration and control of the entire system.

The environmental conditions at the day of the acoustic research were assessed by measurements of water temperature $\left({ }^{\circ} \mathrm{C}\right)$ and concentration of dissolved oxygen $\left(\mathrm{mgO}_{2} \cdot 1^{-1}\right)$, taken through vertical profile at every $0.5 \mathrm{~m}$ at the deepest region of the lake, using the multi-parameter probe Yellow Springs (YSI model 556).

\subsection{Post-processing of acoustic data}

The hydroacoustic data were submitted to a post-processing using software Visual Analyser 4.1 (Biosonics Inc.). The first step was to edit the lake bottom in the software manually. Two types of postprocessing were used, the echo-counting for the analysis of vertical distribution of the spectrum of TS and echo-integration to estimate the fish density.

Analysis of the vertical distribution and of the TS range was performed by echo-counting using $40 \log$ R (TVG - Time Varied Gain) function to compensate the range dependence of the echo and the threshold value of the acoustic energy $-60 \mathrm{~dB}$ for omit echoes of fish smaller than $2 \mathrm{~cm}$ and other unwanted echoes as air bubbles and insect larvae. Echo-counting obtains the number of fish observed and, thereafter, estimates the backscattering crosssection (sigma ou $\sigma b s$ ) of the fish-targets that corresponds to the effective surface reflection of their acoustic energy, assuming a standard spherical reflection, and is related to the proportion of the incident energy which is bacskattered by the target (Target Strength - TS).

The fish-targets length was estimated by Love equation (1977) (Equation 2):

$\mathrm{TS}=19.4 \log (\mathrm{L})-0.9 \log (\mathrm{F})-63.7$

where, $\mathrm{TS}=$ target strength $(\mathrm{dB}) ; \mathrm{L}=$ total length of the body $(\mathrm{cm})$ e $\mathrm{F}=$ frequency $(\mathrm{kHz})$.
The density of fish-targets was made using the echo-integration method, corrected by $20 \log \mathrm{R}$ TVG function. In this method, the total voltage reflected by the echo-integrator was converted to the absolute densities per unit area by scaling the voltage values in the average sigma value determined in the echo-counting of each transect. After the analysis we obtained the number of fish-echoes associated with each transect that, using covered area and observed volume (volume of the sonar beam), were converted into density values per unit area (organisms per hectare). In the spatial density distribution of the echoes associated with fish was used kriging interpolation method, using the Surfer program version 8.0 (Golden Software Inc.). The geostatistical method has been proposed by several authors (e.g, Świerzowski, 2003; Monteoliva and Schneider, 2005), for interpolating data of fish abundance.

\section{Results}

\subsection{Water temperature and dissolved oxygen concentration}

Measurements of temperature in water indicated the virtual absence of thermal stratification, which is typical of tropical lakes for this time of year (Figure 3). There was little variation in temperature between the surface and the bottom (less than $1{ }^{\circ} \mathrm{C}$ ).

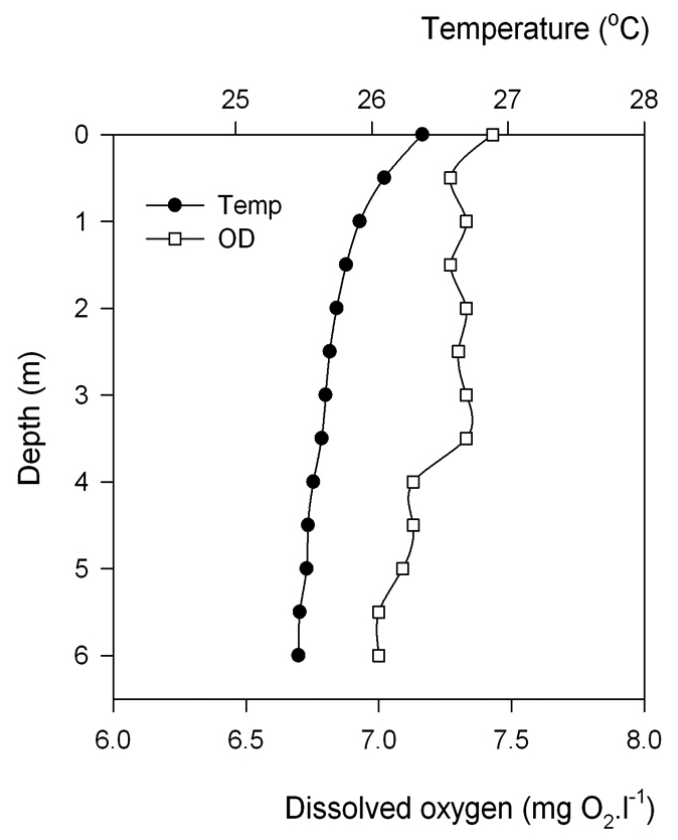

Figure 3. Vertical profiles of temperature $\left({ }^{\circ} \mathrm{C}\right)$ and dissolved oxygen $\left(\mathrm{mg} \mathrm{O}_{2} \cdot \mathrm{l}^{-1}\right)$ in Lagoa Santa (April 28, 2008). 
The water column was well oxygenated, from surface to bottom (more than $7 \mathrm{mgO} \cdot \mathrm{l}^{-1}$ ).

\subsection{Vertical distribution}

Figure 4 shows the vertical distribution of insonified targets in Central Lake during the acoustic survey. The results demonstrate that the organisms were distributed mostly between 3 and 6 meters deep, averaging 4.2 meters (Figure 4). Such behavior can also be revealed in Figure 5, which illustrate an echogram of the pelagic zone (transect 8), where the targets were insonified almost entirely below 3 feet deep.

\subsection{Fish density and body length estimates}

The average TS value obtained by echo-counting in Central Lake was $-52 \mathrm{~dB}$, varying from $-42.4 \mathrm{~dB}$ to $-57.4 \mathrm{~dB}$. Were detected 106 fish-targets and their length (according to Love equation, 1977) varied from 2.7 a $15.9 \mathrm{~cm}$, averaging $5.3 \mathrm{~cm}$ (Figure 6).

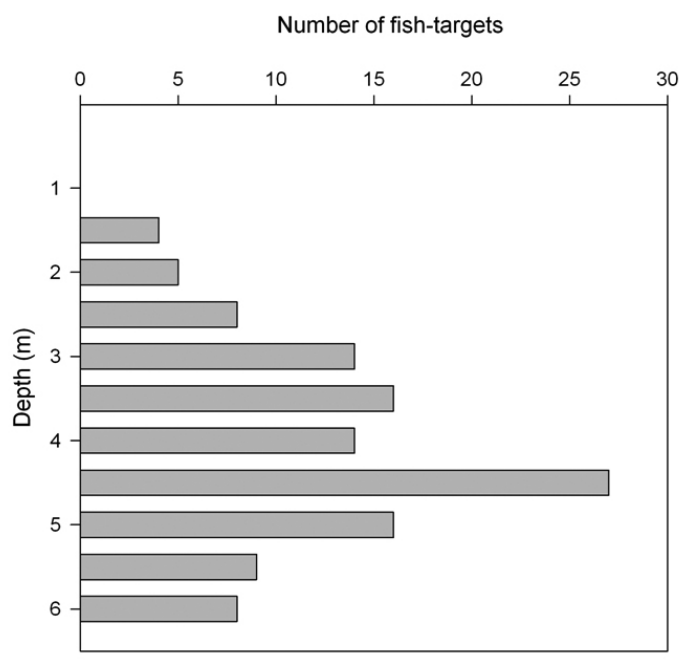

Figure 4. Vertical distribution of all insonified targets through echo-counting technique, by depth strata, in Lagoa Santa, April 28, 2008.

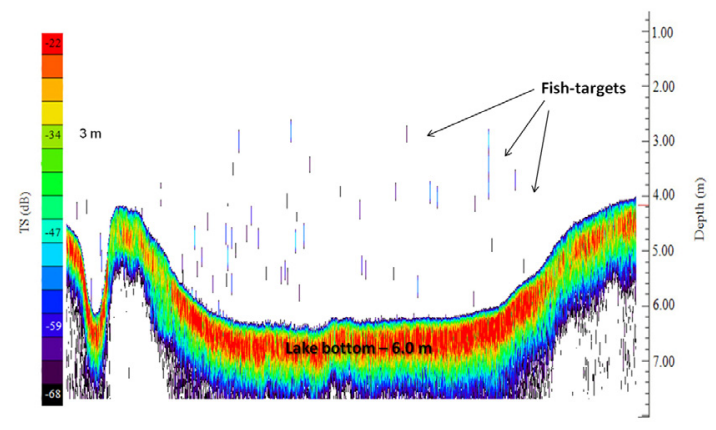

Figure 5. Example of an echogram (transect 8) from vertical sounding realized at Lagoa Santa, April 28, 2008.
The densities of the fish-echoes showed a high spatial heterogeneity, with higher concentration near the coastal zone (Figure 7). The densities ranged from 0 to 18 ind. $\mathrm{m}^{-2}$, with an average of 0.89 ind. $\mathrm{m}^{-2}$.

\section{Discussion}

This was the first study using the hydroacoustic technique in a natural lake of Minas Gerais State (Brazil). The study was able to detect that there are two notable patterns in the spatial distribution of fish: (a) higher concentration near the coastal zone and (b) prevalence of individuals at greater depths, preventing surface water, which indicates that the presence of high dissolved oxygen concentrations throughout the water column favored the occurrence of fish in deeper waters during the day. Additionally, this study was able to estimate the total fish density in the lake. The estimate echoes associated with fish is consistent with the hypothesis that the lake has a low fish density.

Regarding the high fish density close to the coastal zone, this pattern is consistent with the
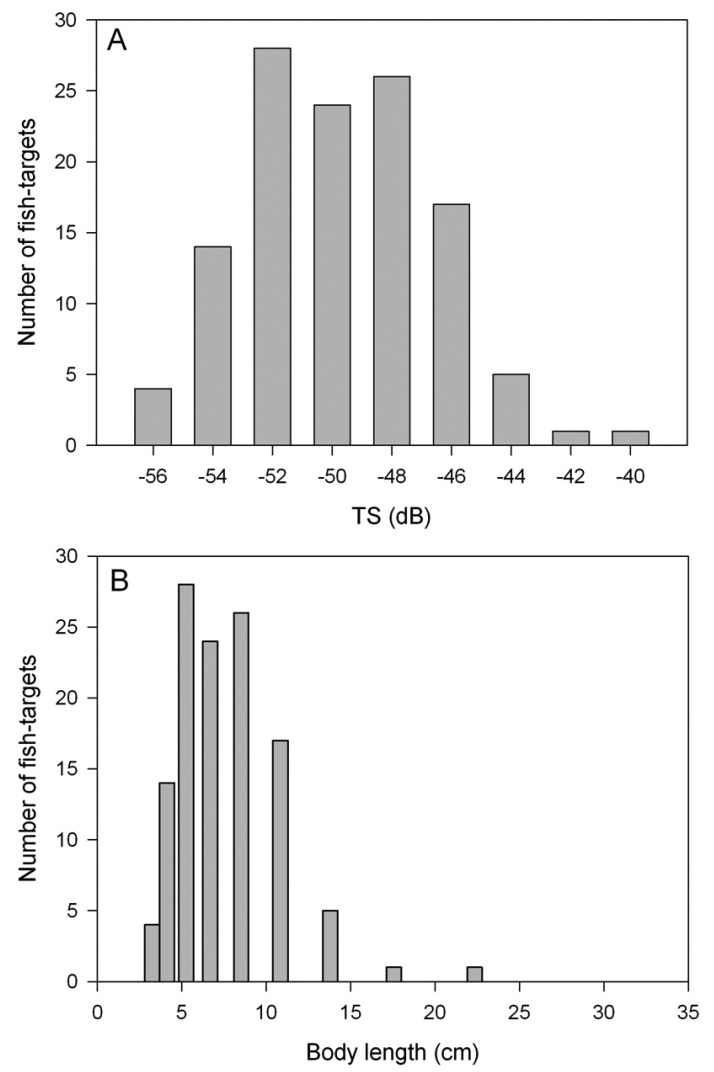

Figure 6. TS distribution (A) and body length distribuition in centimeters (B) of all echoes associated with fish acquired by echo-counting, Lagoa Santa, April 28, 2008. 


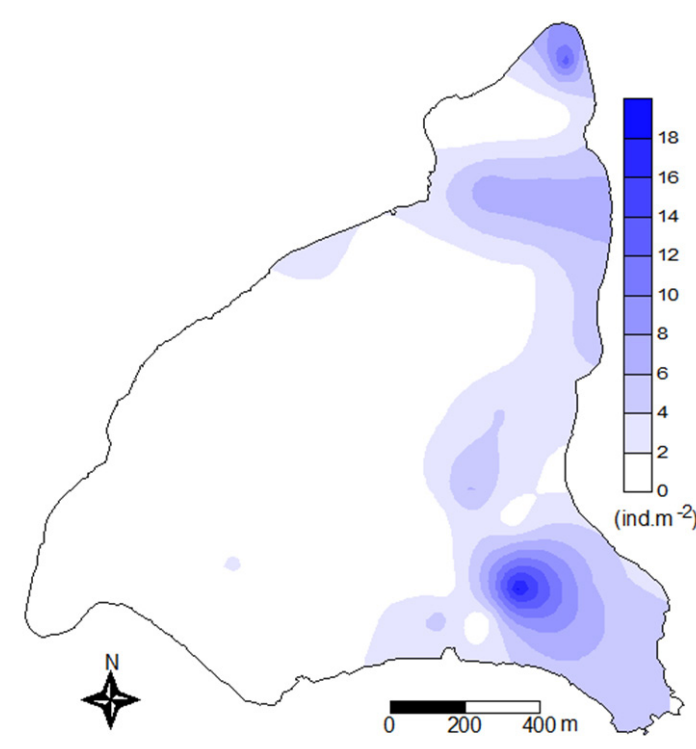

Figure 7. Surface model (kriging) of fish-targets density distribution per unit area (ind. $\mathrm{m}^{-2}$ ) derived from echointegration data collected in Lagoa Santa, April 28, 2008. Data obtained by probing with the Biosonics DT-X.

described in the literature about fish spatial distribution in reservoirs. Once, true pelagic species are rare in South American waters (Agostinho et al. 1999; Gomes and Miranda, 2001).

The echoes associated with fish at depths less than 1 meter were probably subsampled by the echo sounder as a consequence of the transducer depth $(0.5 \mathrm{~m})$ and the "dead zone" that is formed in the region immediately below it. Another reason could be linked to the escape of organisms due to the advancement of the boat during the survey. It would be interesting, in future studies, measure the noise of the vessel. A possible solution to these vertical approach difficulties, like the sampling of coastal regions and surface layers of the water column, can be the use of horizontal hydroacoustic, in which the transducer is positioned horizontally in the water column. Several authors have used this technique successfully in acoustic survey at shallow areas (Kubecka and Wittingerova, 1998; Knudsen and Sægrov, 2002; Monteoliva and Schneider, 2005), however the horizontal hydroacoustic serve only for echo-counting and not for echo-integration.

The echoes associated with fish differ from the pattern of a typical echogram (shape of "V" inverted). This is due to the pulse duration and rate configured during the survey. For a better resolution of individual targets is desirable shorter pulse duration, while the longer duration is used for long ranges, since the SNR (signal to noise ratio) becomes poor, due to weakening of the signal (Acoustics Unpacked). In turn, the pulse rate sets the rate at which the acoustic energy is sent to the water column. The rate choice is based on the depth of the environment in order to avoid "shadows" of the bottom in the data. The greater the depth, greater should be the interval between pulses, as a result lower is the ideal pulse rate (Peltonen et al., 2006).

With the results obtained through this research, we can conclude that the use of hydroacoustics techniques can eliminate some distortions traditionally contained in censuses and studies of fish fauna in reservoirs and lakes. The monitoring of fish populations by hydroacoustic methods has the advantage of not being destructive and to be fast. Another key issue concerns the ease of operation and portability of the equipment, allowing prospecting in small boats with a small staff. We suggest carrying out the hydroacoustic survey concurrently with the traditional collection to calibrate the transformation algorithms TS in body length and biomass, customizing them to the species found.

\section{Acknowledgments}

This study was supported by Fundação de Amparo à Pesquisa do Estado de Minas Gerais - FAPEMIG (5794- Fapemig/Fundep/UFMG). We thank also to the distance learning program, Fundamentos em Ecologia (3443, FUNDEP).

\section{References}

Acoustics Unpacked. A General Guide for Deriving Abundance Estimates from Hydroacoustic Data. Available from: <http://www.dnr.cornell.edu/ acoustics/AcousticsUnpacked.asp>. Access in: 03 Feb 2009.

AGOSTINHO, AA., MIRANDA, LE., BINI, LM., GOMES, LC., THOMAZ, SM. and SUZUKI, HI. 1999. Patterns of colonization in neotropical reservoirs, and prognoses on aging. In TUNDISI, JG. and STRASKRABA, M., ed. Theoretical reservoir ecology and its applications. São Carlos: International Institute of Ecology; Leiden: Backhuys Publishers; Rio de Janeiro: Brazilian Academy of Sciences. p. 227-265.

BRIGHENTI, LS., GONZAGA, AV., BEZERRANETO, JF. and PINTO-COELHO, RM. 2011. Parâmetros morfométricos da Lagoa Central (Lagoa Santa, Minas Gerais): comparaçấo de duas metodologias. Acta Scientiarum: Biological Science, vol. 33 , no. 3, p. 281-287. 
CARVALHO, EJ., FREITAS, JR., KOHLER, HC. and SANTOS, FMC. 1977. Inventário geo-ecológico da regiāo da Lagoa Santa - MG. Belo Horizonte: COPAER. Relatório técnico COPAER.

CHEN, D., ZHANG, X., TAN, X., WANG, K., QIAO, Y. and CHANG, Y. 2009. Hydroacoustic study of spatial and temporal distribution of Gymnocypris przewalskii (Kessler, 1876) in Qinghai Lake, China. Environmental Biology of Fish, vol. 84, no. 2, p. 231-239. http:// dx.doi.org/10.1007/s10641-008-9430-y

EHRENBERG, JE. and STEIG, TW. 2003. Improved techniques for studying the temporal and spatial behavior of fish in a fixed location. Journal of Marine Science, vol. 60, no. 3, p. 700-706.

GERLOTTO, F. 1993. Identification and spatial stratification of tropical fish concentrations using acoustic populations. Aquatic Living Resources, vol. 6, no. 3, p. 243-254. http://dx.doi.org/10.1051/ alr: 1993025

GODLEWSKA, M. and JELONEK, M. 2006. Acoustical estimates of fish and zooplankton distribution in the Piaseczno reservoir, Southern Poland. Aquatic Ecology, vol. 40, no. 2, p. 211-219. http://dx.doi. org/10.1007/s10452-004-3525-0

GOMES, LC. and MIRANDA, LE. 2001. Riverine characteristics dictate composition of fish assemblages and limit fisheries in reservoirs of the Upper Paraná River Basin. Regulated Rivers: Research \& Management, vol. 17, no. 1, p. 67-76. http://dx.doi.org/10.1002/10991646(200101/02)17:1\%3C67::AIDRRR615\%3E3.0.CO;2-P

KRUMME, U. 2004. Patterns in tidal migration of fish in a Brazilian mangrove channel as revealed by a split-beam echosounder. Fisheries Research, vol. 70, no. 1, p. 1-15. http://dx.doi.org/10.1016/j. fishres.2004.07.004

KNUDSEN, FR. and SÆGROV, H. 2002. Benefits from horizontal beaming during acoustic survey: application to three Norwegian lakes. Fisheries Research, vol. 56, no. 2, p. 205-211. http://dx.doi. org/10.1016/S0165-7836(01)00318-6

KUBECKA, J. and WITTINGEROVA, M. 1998. Horizontal beaming as a crucial component of acoustic fish stock assessment in freshwater reservoirs. Fisheries Research, vol. 35, no. 1-2, p. 99-106. http:// dx.doi.org/10.1016/S0165-7836(98)00064-2

LOVE, RH. 1977. Target strength of a fish at any aspect. Journal of the Acoustical Society of America, vol. 62, no. 6, p. 1397-1403. http://dx.doi. org/10.1121/1.381672

MacLENNAN, DN. and HOLLIDAY, DV. 1996. Fisheries and plankton acoustics: past, present and future. Journal of Marine Science, vol. 53, no. 2, p. 513-516.
MADUREIRA, LSP. and ROSSI-WONGTSCHOWSKI, CLD. 2005. Prospecção de recursos pesqueiros pelágicos na Zona Econômica Exclusiva da Região Sudeste-Sul do Brasil: hidroacústica e biomassas. São Paulo: Instituto Oceanográfico, USP. Série Documentos REVIZEE.

MEHNER, T. and SCHULZ, M. 2002. Monthly variability of hydroacoustic fish stock estimates in a deep lake and its correlation to gillnet catches. Journal of Fish Biology, vol. 61, no. 5, p. 1109-1121. http:// dx.doi.org/10.1111/j.1095-8649.2002.tb02459.x

MONTEOLIVA, A. and SCHNEIDER, P. 2005. Aplicación de un nuevo método para la evaluación censal de la ictiofauna de embalses: hidroacústica digital con haz vertical y horizontal. Limnetica, vol. 24, no. 1-2, p. 161-170.

PARAMO, J., QUIÑONES, RA., RAMIREZ, A. and WIFF, R. 2003. Relationship between abundance of small pelagic fishes and environmental factors in the Colombian Caribbean Sea: an analysis based on hydroacoustic information. Aquatic Living Resources, vol. 16, no. 3, p. 239-245. http://dx.doi. org/10.1016/S0990-7440(03)00043-3

PELTONEN, H., MALINEN, T. and TUOMAALA, A. 2006. Hydroacoustic in situ target strength of smelt (Osmerus eperlanus (L.)). Fisheries Research, vol. 80, no. 2-3, p. 190-195. http://dx.doi.org/10.1016/j. fishres.2006.03.033

POMPEU, PS. and ALVES, CBM. 2003. Local fish extinction in a small tropical lake in Brazil. Neotropical Ichthyology, vol. 1, no. 2, p. 133-135.

SANTOS, MBL., ROCHA, LA., MARQUES, MMGSM. and BARBOSA, FAR. 1998. Diversidade e abundância da fauna bentónica de cinco lagoas do karste do planalto de Lagoa Santa, Minas Gerais. Oecologia Brasiliensis, vol. 5, no. 1, p. 77-89. http:// dx.doi.org/10.4257/oeco.1998.0501.06

SIMMONDS, EJ. and MacLENNAN, DN. 2005. Fisheries Acoustics. Oxford: Blackwell Science.

ŚWIERZOWSKI, A. 2003. The variability of distribution and density of pelagic fishes in the Roznowski dam reservoir. Archieves of Polish Fisheries, vol. 11, no. 2, p. 245-263.

TRAVASSOS, P., HAZIN, FHV., ZAGAGLIA, JR., ADVINCULA, R. and SCHOBER, J. 1999. Thermohaline structure around seamounts and islands off Northeast Brazilian coast. Archive of Fishery and Marine Research, vol. 47, no. 2-3, p. 211-222.

TREVORROW, MV. 1998. Salmon and herring school detection in shallow waters using sidescan sonars. Fisheries Research, vol. 35, no. 1-2, p. 5-14. http:// dx.doi.org/10.1016/S0165-7836(98)00054-X

UIEDA, VS. and CASTRO, RMC. 1999. Coleta e fixação de peixes de riachos. In CARAMASCHI, EP., MAZZONI, R. and PERES-NETO, PR., orgs. Ecologia de Peixes de Riachos. Rio de Janeiro: PPGEUFRJ. p. 1-22. Série Oecologia Brasiliensis, vol. VI. 
VEHANEN, T., JURVELIUS, J. and LAHTI, M. 2005. Habitat utilization by fish community in a short-term regulated river reservoir. Hydrobiologia, vol. 545, no. 1, p. 257-270. http://dx.doi.org/10.1007/ s10750-005-3318-z

WANZENBÖCK, J., MEHNER, T., SCHULZ, M., GASSNER, H. and WINFIELD, IJ. 2003. Quality assurance of hydroacoustic surveys: Repeatability of fish abundance and biomass estimates in lakes within and between hydroacoustic systems. Journal of Marine Science, vol. 60, no. 3, p. 486-492.

WHEELER, P. 2005. Utility of digitally modeled and visualized time-series hydrographic charts in analysis of pre/post flood event bathymetric change. Applied Gis, vol. 1, no. 3, p. 24-29.
WINFIELD, IJ., ONOUFRIOU, C., O'CONNELL, MJ., GODLEWSKA, M., WARD, RM., BROWN, AF. and YALLOP, ML. 2007a. Assessment in two shallow lakes of a hydroacoustic system for surveying aquatic macrophytes. Hydrobiologia, vol. 584, no. 1, p. 111-119. http://dx.doi.org/10.1007/s10750-0070612-y

WINFIELD, IJ., FLETCHER, JM. and JAMES, JB. 2007b. Seasonal variability in the abundance of Arctic charr (Salvelinus alpines L.) recorded using hydroacoustics in Windermere, UK and its implications for survey design. Ecology of Freshwater Fisheries, vol. 16, no. 1, p. 64-69. http://dx.doi. org/10.1111/j.1600-0633.2006.00170.x

Received: 07 August 2012 Accepted: 15 July 2013 